\title{
DEMOCRATIC LEGITIMACY AND RESPECT FORHUMAN RIGHTS: THE NEW GOLD STANDARD
}

\author{
Christina M. Cerna*
}

Erika de Wet argues ${ }^{1}$ that state practice reveals that democratic legitimacy has not established itself alongside effective control for the purpose of recognition of governments in customary international law. My response is that we do not need to look to custom, difficult as it is to identify, when we have legally binding obligations such as those set forth in both the OAS Charter and the Inter-American Democratic Charter (IADC), not to mention the comparable European and African instruments. The new gold standard for recognition, I submit, is democratic legitimacy and respect for human rights, which has replaced "effective control."

\section{Introduction}

The inter-American system, also known as the Organization of American States (OAS), is currently engaged in defining the guidelines and objectives ${ }^{2}$ of its strategic vision for the twenty-first century. The four pillars are: democracy, human rights, integral development, and multidimensional security. In January 1979 (when I joined the OAS), many of the countries in the region were governed by military dictatorships or autocrats, such as Duvalier (Haiti), Pinochet (Chile), Stroessner (Paraguay), Videla (Argentina), Somoza (Nicaragua), and Figueiredo (Brazil). At that time, discussion in the OAS of the right to democracy or how to consolidate democracy in the hemisphere would have been inconceivable.

Europe

By the late 1980s, "democracy" had entered the universal Zeitgeist. On July 6, 1989, Mikhail Gorbachev made his famous address to the Council of Europe on "Europe as a Common Home," and the Berlin Wall fell in November of that year provoking the unification of formerly eastern and western Europe. On November 21, 1990, the states participating in the Conference on Security and Co-operation in Europe "at a time of profound change and historic expectations" declared in the Charter of Paris ${ }^{3}$ that they "undertake to build, consolidate and strengthen democracy as the only system of government of our nations" [emphasis added].

* Christina M. Cerna retired from her post as Principal Human Rights Specialist, Inter-American Commission on Human Rights, Organization of American States at the end of December 2011 and is currently Adjunct Professor, Georgetown University Law Center.

Originally published online 23 Jan. 2015.

${ }^{1}$ Erika de Wet, From Free Town to Cairo via Kiev: The Unpredictable Road of Democratic Legitimacy in Governmental Recognition, 108 AJIL UnBOUND 201 (2015).

2 Organization of American States [OAS], Guidelines and Objectives of the Strategic Vision of the Organization of American States, OEA/Ser.P AG/doc.5 (XLVII-E/14) (Sept. 12, 2014).

${ }^{3}$ Charter of Paris For A New Europe, Meeting of Heads of State or Government of the participating States of the Conference on Security and Co-operation in Europe (CSCE), Nov. 21, 1990, 30 I.L.M. 193 (1991).

ASIL and Christina M. Cerna (C) 2015 
To this end they declared that " $[\mathrm{h}]$ uman rights and fundamental freedoms are the birthright of all human beings, are inalienable and are guaranteed by law. Their protection and promotion is the first responsibility of government." It should be noted that France, Germany, Italy, the United Kingdom, the United States, and the USSR were among the states that adopted the Charter of Paris. This was followed by perhaps the most dramatic development in the course of the twentieth century-Gorbachev's dissolution of the Soviet Union in 1991. The end of the Soviet Union also portended the end of the Warsaw Pact and the Cold War, prematurely as it turned out.

In 1989, the Council of Europe comprised 23 states. Today, with the incorporation of the states that formerly comprised central and eastern Europe, it comprises 47 states. Membership in the Council of Europe requires states to become parties to the European Convention on Human Rights and its Protocols. In adopting democratic forms of government, they also sought to adopt the western European value system defined by Europe's most important regional human rights treaty. Remarkably, in 1996, the Russian Federation also became a member and it too acceded to the European Convention on Human Rights and its Protocols and agreed to permit individuals and groups to present complaints against it to the European Commission and now to the European Court of Human Rights. The West's failure to assist and to anchor the Russian Federation in Europe, especially in the early 1990s, has led to the inevitable conflict with Ukraine, which, like its neighbors, prefers to define its future in the West rather than in an alliance with Russia.

\section{The Americas}

In the 1980s and early '90s, as military dictatorships ceded power to civilian governments, one of the first acts of these new civilian governments was to become parties to the American Convention on Human Rights. In 1991, the OAS General Assembly, held in Santiago, Chile (a year after Chile's return to a democratic rule after a seventeen-year military dictatorship), celebrated that for the first time the governments of all the OAS member states were the result of democratic elections except for Cuba, the government of which had been suspended from participation since 1962. The government, but not the state, was suspended following Fidel Castro's declaration that he was a Marxist-Leninist, considered by the OAS to be a voluntary departure from the principle of representative democracy set forth in the OAS Charter. It should be noted that military dictatorships throughout the region during the 1970s and '80s were never suspended from the OAS for having voluntarily departed from the principles of the OAS Charter.

In order to prevent future coups in the region, this General Assembly adopted Resolution 1080, ${ }^{4}$ whereby the Secretary General was instructed to immediately convene a meeting of the Permanent Council in the event of any occurrence giving rise to the sudden or irregular interruption of the democratic process. The Council was to decide within ten days whether to convene an ad hoc Meeting of Ministers of Foreign Affairs or a special session of the General Assembly. In either forum, the foreign ministers were to adopt any decisions they deemed appropriate in accordance with the OAS Charter and international law. Resolution 1080 was applied first in Haiti following the coup d'etat against President Jean-Bertrand Aristide, who was overthrown by a military coup on September 30,1991. It was applied again in Peru, in April 1992, and Guatemala, in May 1993, when the interruptions of the democratic process were not caused by a military coup but rather by the executive's attempt to consolidate all three branches of power by means of a self-coup (autogolpe).

The Protocol of Washington (1992), inter alia, amended Article $9^{5}$ of the OAS Charter and introduced sanctions (i.e. suspension from OAS activities) when a democratically constituted government of a member

${ }^{4}$ OAS, Representative Democracy, AG/RES. 1080 (XXI-O/91) (June 5, 1991).

5 OAS, Protocol of Amendments to the Charter of the OAS, "Protocol of Washington", A-56 (Dec. 14, 1992). 
state was overthrown by force. Resolution 1080 and amended Article 9 of the OAS Charter became the building blocks for the adoption of the Inter-American Democratic Charter ${ }^{6}$ on September 11, 2001.

In this observer's view, the IADC's most important innovation is that it conflates democracy and human rights and declares democracy a human right: "the peoples of the Americas have a right to democracy and their governments have an obligation to promote and defend it" [emphasis added]. Freedom of speech, the right to petition, to assemble, to stand for public office, to vote-civil and political rights are rights that can only be exercised in a state with a democratic form of government. Similarly the rights to access a court, to due process, to a fair trial, are rights that require an independent judiciary, one of the three branches of government in a democracy.

Article $20^{7}$ of the IADC provides for collective action if the democratic regime is altered or interrupted. Unlike amended Article 9 of the OAS Charter, which specifically refers to the overthrow "by force" of a democratically elected government, the test in Article 20 is whether there has been "an unconstitutional alteration of the constitutional regime that seriously impairs the democratic order," which requires a determination at the domestic level. Article 21 of the IADC provides for the possible suspension of a member state.

The OAS Charter and the IADC are legally binding instruments 8 that establish mechanisms to address the impairment of the democratic order in member states of this hemisphere. They call for collective action to respond to a quintessentially domestic political circumstance, again, a situation traditionally identified with violations of international human rights.

The most serious test of the IADC occurred with the June 28, 2009 coup d'état against Honduran President Manuel Zelaya and his expatriation to Costa Rica. The coup was sanctioned by the Honduran legislature and the Supreme Court after Zelaya called for a referendum to rewrite the constitution. His opponents feared he would use it to extend his term in office as Hugo Chavez had done in Venezuela. The same day the President of the National Congress, Roberto Micheletti, was installed as President. The OAS Permanent Council, convened and adopted resolution CP/RES. 953 (1700/09) "Current Situation in Honduras" and condemned the coup d'état and President Zelaya's expulsion. It demanded his reinstatement and declared that no government arising from the coup would be recognized.

On July 1, 2009, the OAS General Assembly held a special session, at which President Zelaya was present, and approved Resolution AG/RES. 1 (XXXVII-E/09) "Resolution on the Political Crisis in Honduras,"10 resolving not to recognize any government arising from this "unconstitutional interruption." The de facto government was given seventy-two hours in which to reinstate President Zelaya or face suspension. On July 3, OAS Secretary General Insulza traveled to Honduras, where he met with the Chief Justice of the Supreme Court and other authorities and informed them of the actions taken by the OAS. On July 4, the Secretary General informed the General Assembly that the de facto regime refused to comply with the provisions of the July 1 resolution. Consequently on July 4, 2009, the OAS General Assembly approved Resolution AG/RES. 2(XXXVII-E/09) "Suspension of the right of Honduras to participate in the Organization of American States"11 and suspended Honduras pursuant to the IADC. In addition, it called upon the Inter-American

${ }^{6}$ OAS, Inter-American Democratic Charter, Sept. 11, 2001.

$7 \underline{I d}$.

${ }^{8}$ Lelia Mooney, Introductory Note to the Inter-American Juridical Committee: Resolution on the Essential and Fundamental Elements of Representative Democracy and Their Relation to Collective Action Within the Framework of the Inter-American Democratic Charter, 48 I.L.M. 1233 (2009).

${ }_{9}$ OAS, Current Situation in Honduras, OEA/Ser.G CP/RES. 953 (1700/09) (June 28, 2009).

${ }^{10}$ Christina M. Cerna, Introductory Note to Recent OAS Documents on Cuba and Honduras: Democracy and the Inter-American Democratic Char$\underline{\text { ter, }}, 48$ I.L.M. 1242 (2009).

11 OAS, Suspension of the Right of Honduras to Participate in the Organization of American States, OEA/Ser.p AG/RES.2 (XXXVII-E/09) rev. 1 (July 16, 2009). 
Commission to continue to protect and defend human rights in Honduras. The Inter-American Commission carried out an on-site visit to Honduras from August 17-21, 2009 and issued its report: "Honduras: Human Rights and the Coup d'Etat," 12 in which it confirmed the loss of legitimacy brought about by the coup and also detailed the serious human rights violations that had taken place, especially the persecution of supporters of the Zelaya government.

President Zelaya was never reinstated, and on November 29, 2009, Porfirio Lobo was elected President. The Inter-American Commission carried out a follow up visit during May 15-18, 2010 and expressed deep concern over the continuation of human rights violations against persons who participated in activities against the coup d'état. In June 2011, Honduras was readmitted to the OAS following an agreement reached between Porfirio Lobo and Manuel Zelaya in Cartagena, Colombia on May 22, 2011, an agreement facilitated by Colombia and Venezuela. The vote to readmit Honduras was opposed by only one country, Ecuador.

The Cartagena Accord ${ }^{13}$ was designed to put an end to the persecution of Zelaya and his supporters and to ensure his safe return to Honduras from the Dominican Republic; to organize a national plebiscite on reforming the country's fundamental laws; to further respect for human rights and the investigation of possible violations; and to provide guarantees that Zelaya supporters would be permitted to participate in Honduras' political life and in 2013 elections as a political party. All charges against Zelaya were dropped, and he returned to Honduras on May 28, 2011. Since Zelaya could not compete in the 2013 elections, his wife Xiomara Castro did. She led in the polls until shortly before the elections, when she fell to second place behind the then President of the National Congress, Juan Orlando Hernández, who won the elections 34 to 29 percent in a field of eight candidates. Orlando Hernández was inaugurated President of Honduras in January 2014. What is important about the Honduran case is that the OAS immediately condemned the coup, refused to recognize the de facto government of Micheletti, and was actively engaged in seeking to assist in the resolution of the internal problems.

To argue that state practice pertaining to democratic legitimacy as a requirement for recognition is still too inconsistent to constitute customary international law demands a level of compliance at a relatively early stage following the crystallization and codification of the norm of democratic legitimacy that ignores political realities. To analogize, the international law prohibition on torture is generally accepted as absolute; no country in the world permits laws authorizing torture. Yet, in May 2014, Amnesty International ${ }^{14}$ announced that torture is practiced by authorities all over the world. Does inconsistent state practice undermine the legitimacy of the international prohibition of torture or deprive it of its authority as a norm of customary international law? Some have argued that the entire Universal Declaration of Human Rights has become customary international law, although Professor Hurst Hannum ${ }^{15}$ and others disagree, but at least there appears to be agreement that the prohibition on the state practice of torture is universal. Whether that prohibition has achieved the status of a customary international norm is debatable since state practice is what it is, but is it necessary to resort to custom when human rights treaties all prohibit torture?

\footnotetext{
12 Inter-American Commission on Human Rights, OAS, Honduras: Human Rights and the Coup d'etat, OEA/Ser.V/V/II. Doc. 55 (Dec. 30, 2009).

13 The Cartagena Accord, Honduras Culture And Politics (May 22, 2011).

14 Priyanka Boghani, 13 Startling Facts from Amnesty's Report on Torture Around the World, Global Post (May 14, 2014).

${ }^{15}$ Hurst Hannum, Human Rights, in THE United NATIONS AND InTERnATIONAL LAW 131 (Christopher C. Joyner ed., 1997).
} 
Whether the treaty mechanisms created are sufficient and adequate to guarantee democracy in the Americas at this stage is doubtful. The treaty mechanisms, however, define democracy as the norm, and any unconstitutional interruption of democracy creates an abnormal situation. Europe, the Americas, and Africa all recognize democratic governments today as the norm, unlike the United Nations, and they convert the "interruption" of the democratic process into an issue of regional concern. It opens a door that in the past was closed, and that alone is a huge step forward. We can now discuss the interruption of the democratic order in the region, recognizing that this has created an abnormal situation that must be corrected. This was not possible thirty-five years ago.

This experience of the OAS inspired the African Union to introduce a provision similar to Article 9 of the amended OAS Charter into Article 4(p) of its Constitutive Act ${ }^{16}$ and also to adopt the African Charter on Democracy, Elections, and Governance. ${ }^{17}$ Although Africa continues to suffer coups, these coups are condemned, they lead to the suspension of the affected government, and the resolution of the interruption of the democratic order has become a consistent concern of the African Union. This is a far cry from 1981, when the OAU adopted the African Charter on Human and Peoples' Rights, ${ }^{18}$ in which no mention was made of the word "democracy" or a democratic form of government.

Should President Zelaya have been reinstated or did he contribute, or even cause, the erosion of democracy in Honduras? These are political questions and their resolution in such deeply polarized societies is best left to the national level, not to international bodies. Article 20 of the IADC defines the test as whether there has been "an unconstitutional alteration of the constitutional regime," and this is an explicit renvoi to domestic law, for only the highest court at the national level is competent to determine whether the constitutional regime has been altered. In the Honduran case, aside from the illegal coup, two branches of government, the legislature and the Supreme Court, alleged that the executive's actions were unconstitutional.

The OAS, however, is only permitted to do what the government of the interested member state consents to or requests. OAS Secretary-General Jose Miguel Insulza ${ }^{19}$ has noted that one of the difficulties in applying the IADC in practice is that governments tend not to seek its application. Since only the Executive Branch can invoke the IADC, requests for its application, coming from countries in which the separation of powers is threatened or compromised, are not addressed. It has been suggested that making the OAS's resources available to any branch of government that believes that the country's constitution is being violated would be a major step forward. It would enable the OAS to take preventive action before a crisis erupts, to define much more explicitly what constitutes a serious interruption of the democratic process, and to respond with measures other than just suspension.

\section{Conclusion}

In conclusion, I would submit that "effective control" has been replaced as the gold standard for recognition by a test that combines democratic legitimacy and respect for human rights. Approximately 134 of 193 UN member states have extended diplomatic recognition ${ }^{20}$ to Palestine. Since Palestine argues that Gaza and the West Bank are "occupied" territories, a position that Israel contests (calling them "disputed" territories),

16 Organization of African Unity [OAU], Constitute Act of the African Union [AU], July 11, 2000.

17 AU, African Charter on Democracy, Elections, and Governance, Jan. 30, 2007.

18 OAU, African (Banjul) Charter on Human and Peoples' Rights, OAU Doc. CAB/LEG/67/3 rev. 5, 21 I.L.M. 58 (June 27, 1981).

${ }^{19}$ OAS Secretary General, Report Concerning Compliance with Operative Paragraph 3 of Resolution AG/RES. 2480 (XXXIX-O/09): "Promotion and Strengthening of Democracy: Follow-Up to the Inter-American Democracy Charter", Doc. No. OEA/Ser.G CP/doc.4487/10 (May 4, 2010).

${ }^{20}$ Stephen Castle \& Jodi Rudoren, A Symbolic Vote in Britain Recognizes a Palestinian State, N.Y. Times (Oct. 13, 2014). 
then the territory that Palestine is claiming sovereignty over is simultaneously acknowledged to be effectively controlled by another state. The recognition of Palestine, I would argue, is based on human rights considerations - the vindication of the right to exist of a people whose territory was taken over by an alien population, whose importation was facilitated by the West—and not a Palestinian claim to effective control over territory.

Similarly, no one seriously protested the ouster of Yanukovych, Qaddafi, Mubarak, or even Morsi, because, like Zelaya, exercising effective control by military force over territory was no longer sufficient to accord legitimacy. Even al-Sisi, who overthrew Morsi in a military coup, was applauded by an important segment of the population for having prevented the Islamization of Egypt and he took off his military uniform and stood for elections. Standing for elections is an attempt to conform to the demands of democratic legitimization, although it is clear that the perpetrator of the coup (especially against a democratically elected head of state) should be prevented from turning himself into a candidate, or else risk being portrayed as another Pinochet.

Al-Sisi's failure to respect human rights, by incarcerating tens of thousands of Morsi supporters and subjecting them to military, not civilian, jurisdiction has served to undermine his legitimacy. Leaders such as alSisi and Morsi destroyed whatever legitimacy they had gained through elections by failing to respect the human rights of their population. The trend of certain leaders to attempt to bring about transformational changes in their societies by altering the constitution, perpetuating themselves in power, and imposing change with the popular support of only a small minority of the population is doomed to failure.

Even elections, the lowest common denominator in defining a "democratic" form of government, are no longer sufficient to accord legitimacy if the elected leader is violating human rights. Yanukovych misread the will of the Ukrainian people by rejecting closer cooperation with the West in favor of closer ties to the Russian Federation. The Ukrainian people want closer cooperation with the West because they want the democratic values consecrated in the European Convention on Human Rights. But in my view, they're not alone, so do the Russian people. 